\title{
PENGARUH KEPUASAN DAN MOTIVASI KERJA TERHADAP KOMITMEN AFEKTIF GURU SMK NEGERI DI JAKARTA SELATAN
}

\author{
Ahmad Zainul Mizan', Rugaiyah ${ }^{2}$, Nurjannah $^{3}$ \\ Manajemen Pendidikan, Universitas Negeri Jakarta ${ }^{123}$ \\ Email : ahmadzainulmizan@gmail.com ${ }^{1}$
}

\begin{abstract}
Abstrak
Peneliti mengamati keadaan pada guru SMKN di Jakarta Selatan, pengamatan dan wawancara dengan wakil kepala sekolah bidang kurikulum dan kesiswaan menunjukkan adanya kesenjangan antara yang diharapkan dan kenyataan tentang komitmen afektif guru. Berdasarkan data empirik yang diperoleh dari hasil wawancara pendahuluan pada bulan maret 2018 di beberapa SMKN di Jakarta Selatan, diperoleh data bahwa masih rendahnya komitmen afektif guru dalam melaksanakan tugas mengajar. Penelitian ini bertujuan untuk mengetahui pengaruh dari (1) Kepuasan Kerja, (2) Motivasi Kerja, (3) Komitmen Afektif guru SMK Negeri DI Jakarta Selatan. Metode yang digunakan dalam penelitian ini adalah metode penelitian survey dengan pendekatan kuantitatif-kausal dengan menggunakan analisis jalur. Survey dilakukan sejak Juni sampai Juli 2018 dengan melibatkan 164 orang guru di Jakarta Selatan sebagai sampel yang ditentukan secara acak. Temuan dalam penelitan ini menunjukkan: Pertama, terdapat pengaruh langsung kepuasan kerja terhadap komitmen afektif. Kedua, terdapat pengaruh langsung motivasi kerja terhadap komitmen afektif. Ketiga, terdapat pengaruh langsung kepuasan kerja terhadap terhadap motivasi kerja.
\end{abstract}

Kata kunci : Kepuasan kerja, motivasi kerja, dan komitmen afektif.

\begin{abstract}
The researcher's observation of the condition of SMKN (State Vocational High School) teachers in South Jakarta and interview with the deputy headmaster overseeing curriculum and student affairs show a gap between the expectation and the reality of the teacher's affective commitment. Based on empirical data obtained from preliminary interviews in March 2018 in several SMKNs in South Jakarta, it is seen that the teacher's affective commitment to teach is still low. This research aims to know the effects of (1) Job Satisfaction, (2) Work Motivation, (3) Affective Commitment of SMKN teachers in South Jakarta. The method used is a survey research method with a quantitative-causal approach using path analysis. The survey is conducted from June to July 2018 by involving samples of 164 teachers randomly taken in South Jakarta. The findings in the research show: First, there is a direct effect of job satisfaction on affective commitment. Second, there is a direct effect of work motivation on affective commitment. Third, there is a direct effect of job satisfaction on work motivation.
\end{abstract}

Keywords: Job satisfaction, work motivation and affective commitment.

\section{PENDAHULUAN}

Komitmen guru dalam memberikan pengetahuan, tenaga serta pikiran kepada siswa adalah hal yang sangat penting guna mencapai tujuan pendidikan. Guru sebagai sumber daya sekolah dituntut memiliki komitmen yang tinggi agar dapat menjalankan fungsinya sebagai pengajar yang berdedikasi.

Komitmen organisasi paling sering didefinisikan sebagai (1) keinginan yang kuat untuk tetap menjadi anggota organisasi tertentu; (2) kesediaan untuk mengerahkan upaya tingkat tinggi atas nama organisasi; dan (3) keyakinan yang pasti dan penerimaan terhadap nilai dan tujuan organisasi.

Komitmen guru tercermin dalam perilakunya pada pelaksanaan tugas pokoknya sebagai guru dan keterlibatan pada kegiatan sekolah, apakah dengan bangga, terpaksa atau hanya pemenuhan tanggungjawab secara moral saja, jika setiap guru memiliki komitmen kuat pada sekolah, 
maka kendala apapun yang ada di sekolah tidak akan menurunkan semangat untuk mempersembahkan yang terbaik untuk peserta didik di sekolah. Sebagaimana yang dikatakan oleh Engin Karadag, et, al, dalam penelitiannya "Teacher commitment has gradually been recognised in the leadership literature as the most effective route to school success."[1] Komitmen guru secara bertahap telah diakui dalam literatur kepemimpinan sebagai rute yang paling efektif untuk keberhasilan sekolah.

Penelitian yang relevan dengan variable penelitian, salah satunya adalah penelitian yang menginvestigasi tentang variabel yang mempengaruhi komitmen afektif. Penelitian ini dilakukan di Libya untuk 96 sekolah dasar negeri dengan populasi 633 guru dengan judul Factors that influence Affective Commitment to teaching in Libya :

Overall job satisfaction was the second strongest correlated variable in relation to affective commitment. Teachers increase the sense of commitment when satisfaction has been attained about overall job satisfaction, job security, meaning of job, feelings of satisfaction towards teaching staff and principals, and growth and development opportunities at school.[2]

Secara keseluruhan kepuasan kerja adalah variabel terkuat kedua terkuat dalam kaitannya dengan komitmen afektif. Guru meningkatkan rasa komitmen ketika kepuasan telah tercapai tentang kepuasan kerja secara keseluruhan, keamanan kerja, makna pekerjaan, perasaan puas terhadap staf pengajar dan kepala sekolah, dan peluang pertumbuhan dan pengembangan di sekolah.

Guru yang memiliki komitmen dalam bekerja khususnya komitmen afektif juga dapat terlihat dari sikap yang ditunjukkan terhadap institusi sekolah berupa sikap senang sebagai guru, bangga terhadap sekolah, peduli terhadap sekolah dan bertanggung jawab dalam tugas mengajar, mampu melibatkan diri sepenuhnya kepada aktivitas-aktivitas sekolah, siap dan bersedia mempertahankan nama baik sekolah serta menunjukkan loyalitas yang tinggi kepada sekolah. Komitmen afektif berkaitan dengan aspek emosional, identifikasi dan keterlibatan guru dalam organisasi sekolah. Komitmen afektif merupakan proses sikap dimana seorang berfikir tentang hubungannya dengan sekolah mempertimbangkan kesesuaian antara nilai dan tujuannya dengan nilai dan tujuan organisasi.

Guru yang memiliki komitmen afektif dalam bekerja juga dapat terlihat dari kemampuan menjadikan dirinya sebagai bagian yang tidak terpisahkan dari kehidupan sekolah, mampu melibatkan dirinya sepenuhnya pada aktivitas-aktivitas sekolah, siap dan sedia mempertahankan nama baik sekolah, serta mempu menunjukkan loyalitas yang tinggi terhadap sekolah. Komitmen afektif guru adalah sikap yang ditunjukkan seorang guru terhadap institusi sekolah yang senang sebagai guru, bangga terhadap sekolah , peduli terhadap sekolah dan bertanggungjawab dalam tugas mengajar.

Faktor-faktor yang diduga mempengaruhi komitmen dalam penelitian ini diantaranya adalah motivasi kerja, motivasi kerja diduga dapat mempengaruhi komitmen afektif guru karena motivasi kerja sangat penting bagi seorang guru, mengingat motivasi merupakan dorongan yang menggerakkan guru untuk bekerja, tanpa adanya motivasi kerja yang baik dari guru, maka mereka akan bekerja apa adanya dan terkesan asal bekerja.

Faktor lain yang diduga pula mempengaruhi komitmen afektif guru yaitu faktor kepuasan kerja. Di dalam Integrative Model of organization Behavior di katakana bahwa 
kepuasan kerja memiliki pengaruh positif yang kuat terhadap komitmen organisasi. Orang yang mengalami tingkat kepuasan kerja yang lebih tinggi cenderung merasakan tingkat komitmen afektif yang lebih tinggi.

Berdasarkan uraian di atas, maka peneliti tertarik untuk melakukan penelitian tetang pengaruh kepuasan kerja dan motivasi kerja terhadap komitmen afektif guru SMK Negeri di Jakarta Selatan.

\section{Komitmen Afektif}

Komitmen muncul sebagai topik penting dalam sebuah penelitian, di dalam organisasi di sekolah komitmen seseorang yang ada di dalam sekolah tersebut sangatlah penting untuk kemajuan sekolah. John M. Ivancevich, at, al., mengatakan dalam bukunya [3] Komitmen adalah perasaan untuk mengidentifikasi, keterlibatan, dan kesetiaan yang diungkapkan oleh karyawan terhadap perusahaan.

Komitmen kepada organisasi menurut John M. Ivancevich, at, al. memiliki tiga sikap diataranya. [4] Komitmen kepada organisasi melibatkan tiga sikap: (1) perasaan untuk mengidentifikasi dengan tujuan organisasi, (2) perasaan keterlibatan dalam organisasi tugas, dan (3) perasaan kesetiaan kepada organisasi. Ricky W. Riffin and Gregory Moorhead juga mengatakan bahwa [5] Komitmen organisasi adalah identifikasi dan keterikatan seseorang dengan suatu organisasi.

Pengertian komitmen afektif menurut Lynne Millward, [6] Komitmen afektif adalah ikatan emosional yang dimiliki individu terhadap organisasinya.

Menurut Colquitt, Lepine dan Wesson, [7] Komitmen afektif dapat di definisikan sebagai keinginan untuk tetap menjadi anggota organisasi karena keterikatan emosional, dan keterlibatan dengan organisasi. Individu yang memiliki komitmen afektif tidak hanya menjadi anggota oraganisasi tetapi memiliki keterikatan emosional untuk terlibat dalam dalam organisasi. Menurut McShane dan Von Glinow, [8] Komitmen organisasi (afektif) adalah keterikatan emosional karyawan dan keterlibatan dalam organisasi tertentu. Definisi ini secara spesifik berkaitan dengan komitmen afektif adalah ikatan emosional, perasaan kesetiaan kepada organisasi.

Komitmen afektif merupakan keterikatan emosional karyawan dalam sebuah organisasi, sehingga individu yang memiliki komitmen afektif yang tinggi memiliki perasaan kesetiaan kepada organisasi. Menurut George dan Jones, Komitmen afektif merupakan Komitmen yang ada ketika karyawan senang menjadi anggota organisasi, percaya dan merasa baik tentang organisasi itu dan apa yang ada pada dirinya melekat pada organisasi, dan berniat untuk melakukan apa yang baik untuk organisasi. Individu yang memiliki komitmen afektif yang tinggi tidak hanya memiliki keterikatan emosional kepada organisasinya tetapi jg akan melkukan yang terbaik untuk organisasinya.

Menurut Fred Luthans, [9] Komitmen afektif melibatkan keterikatan emosional karyawan, dengan identifikasi, dan keterlibatan dalam organisasi.Berdasarkan uraian-uraian yang telah dikemukakan di atas, maka dapat disintesiskan bahwa komitmen Komitmen Afektif adalah keterikatan emosional yang dimiliki seseorang/individu terhadap organisasinya dan keinginan yang untuk tetap menjadi anggota organisasi dengan indicator (1) Keterikatan emosional (2) Keterlibatan dalam organisasi (3) Kesetiaan kepada organisasi (4) Keinginan tetap menjadi anggota organisasi (5) Kepercayaan kepada organisasi. 


\section{Kepuasan Kerja}

Kepuasan kerja merupakan suatu penilaian relatif, yang sangat tergantung dari tanggapan masing-masing individu terhadap pekerjaannya. dalam situasi yang sama, seseorang memiliki tingkat kepuasaan yang berbeda. Dengan demikian sumber kepuasan ditentukan oleh pandangan dan tingkat pemenuhan keinginan seseorang terhadap segala sesuatu yang ada di sekeliling orang tersebut.

Pengertian kepuasan kerja menurut Jason A. Colcuitt, Jeffery A. Lepine and Michael J. Wesson, [10] Kepuasan kerja adalah keadaan emosi yang menyenangkan yang dihasilkan dari penilaian pekerjaan atau pengalaman pekerjaan seseorang.

Menurut George and Jones, [11] Kepuasan kerja adalah kumpulan perasaan dan keyakinan yang dimiliki orang tentang pekerjaan mereka saat ini. Menurut John R. Schermerhorn, et. al., [12] Kepuasan kerja adalah perasaan positif tentang suatu pekerjaan dan pengaturan pekerjaan. Menurut McShane dan Von Glinow, [13] Kepuasan kerja adalah evaluasi seseorang terhadap pekerjaan dan konteks kerjanya. Menurut Kinicki and Robert, [14] Kepuasan kerja merupakan respon yang efektif atau emosi terhadap berbagai pekerjaan seseorang.

Menurut Steve M. Jex, [15] Kepuasan kerja biasanya didefinisikan sebagai tingkat pengaruh positif karyawan terhadap pekerjaan atau situasi pekerjaannya. Selanjutnya Colin P. Silverthorne mengatakan bahwa [16] Kepuasan kerja didefinisikan sebagai ". Keadaan emosi yang menyenangkan atau positif yang dihasilkan dari penilaian pekerjaan seseorang.

Berdasarkan uraian-uraian yang telah dikemukakan di atas, maka dapat disintesiskan bahwa Kepuasan kerja merupakan perasaan positif seseorang tentang pekerjaan yang menyenangkan yang di hasilkan dari penilaian pekerjaannya.

\section{Motivasi Kerja}

Pada dasarnya konsep motivasi itu berhubungan dengan arah prilaku, kekuatan respon, usaha atau inisiatif kemauan dan dorongan serta ketahanan perilaku seseorang dalam proses pencapaian tujuan pada saat tertentu.

Menurut Fred Luthans, [17] Motivasi adalah suatu proses yang memulai secara psikologi atau defesiensi psikologi atau kebutuhan yang mengarahkan perilaku untuk mencapai tujuan secara insentif.

Motivasi di awali adanya kebutuhan dan pengembangannya, perilaku untuk memuaskan kebutuhan tersebut terdiri dari motivasi intrinsic untuk mencapai tujuan tertentu atau menerapkan stabilitas internal. Menurut Stephen P Ribbins and Timothy A Judge [18] Motivasi didefinisikan sebagai proses yang membuat seseorang mengintensifkan arah dan keberlangsungan usaha untuk mencapai tujuan. Huczynski dan Buchanan berpendapat bahwa [19] Motif mempengaruhi perilaku orang yang menuntun kepada usaha mengejar atau mencapai tujuan tertentu karena secara sosial pencapaian tujuan ini bernilai.

Melayu SH. Hasibuan [20] mengatakan bahwa motivasi penting karena dengan motivasi diharapkan setiap individu karyawan mau bekerja keras dan antusias untuk mencapai produktifitas kerja yang tinggi. [21] Menurut syamsudin bahwa motivasi itu merupakan suatu kekuatan (power) atau tenaga (forces) atau daya (energy) atau suatu keadaan yang kompleks dan kesiapan ( preparatory set) dalam diri individu untuk bergerak kearah tujuan tertentu, baik disadari maupun tidak disadari, motivasi tersebut tumbuh dan berkembang dengan jalan (a) dating dalam diri individu (intrinsik), (b) dating dari 
lingkungan (ektrinsik). Motivasi memang muncul dalam diri manusia, tetapi kemunculannya karena terangsang oleh adanya unsur lain, dalam hal ini adalah tujuan yang mengarah kepada kebutuhan. Orang cenderung termotivasi dalam bekerja dikarenakan adanya faktor kepuasan yang tinggi ditempat kerja. Keberhasilan seseorang dalam melaksanakan tugas ditentukan oleh adanya dorongan untuk berhasil menyelesaikan rintangan yang dihadapi untuk mencapai tujuan.

Menurut James, L. Gibson, et, al,. [22] Motivasi adalah konsep yang kita gunakan ketika kita mendeskripsikan gaya yang bekerja pada atau di dalam individu untuk memulai dan mengarahkan perilaku seseorang. Seseorang yang termotivasi akan menyebabkan orang tersebut berperilaku untuk melakukan sesuatu yang baik untuk organisasi seperti yang dikatakan oleh Don Hellriegel and John W. Slocum, [23] Motivasi mewakili kekuatan yang bekerja pada atau di dalam seseorang yang menyebabkan orang tersebut berperilaku tertentu, dengan cara yang diarahkan pada tujuan.

Lain halnya yang dikatakan oleh John R. Schermerhorn, et, al,. [24] Motivasi mengacu pada kekuatan individu yang memperhitungkan arah, level, dan ketekunan dari upaya seseorang yang dikeluarkan di tempat kerja.

Motivasi kerja dianggap penting dalam melakukan kegiatan yang mendorong timbulnya tingkah laku dan mempengaruhi serta mengubah tingkah laku atau perbuatan. Motivasi dapat mengarahkan suatu perbuatan untuk mencapai tujuan yang diinginkan. Motivasi bias mengarahkan tingkah laku seseorang, sehingga besar atau kecilnya motivasi akan menentukan cepat atau lambatnya suatu pekerjaan dapat diselesaikan, tanpa motivasi tidak akan timbul suatu perbuatan (bekerja).
Motivasi kerja dapat diartikan sebagai suatu daya pendorong yang menyebebkan orang berbuat sesuatu, perbuatan ini dapat diartikan kerja keras guna lebih berprestasi, menambah keahlian. Menurut Bereendom dan Gary A Stainer yang dikutip Sedarmayanti bahwa [25] motivasi kerja adalah kondisi mental yang mendorong aktivitas yang memberi energy yang mengerah kepada pencapaian kebutuhan, kepuasan dan mengurangi ketidak seimbangan. Usman Husaini mengatakan bahwa [26] motivasi kerja dapat diartikan sebagai keinginan atau kebutuhan yang melatarbelakangi seseorang sehingga terdorong untuk bekerja. Pengertian motivasi kerja menurut Goerge and Jones, [27] Motivasi kerja dapat didefinisikan sebagai kekuatan psikologis yang menentukan arah perilaku seseorang dalam suatu organisasi, tingkat upaya seseorang dan tingkat ketekunan seseorang.

Menurut Ruth Kanfer et. al , [28] Motivasi kerja umumnya didefinisikan sebagai proses psikologis itu menentukan (atau memberi energi) arah, intensitas, dan ketekunan tindakan dalam aliran pengalaman berkelanjutan yang menjadi ciri orang tersebut dalam kaitannya dengan pekerjaannya.

Berdasarkan uraian-uraian yang telah dikemukakan di atas, maka dapat disintesiskan bahwa Motivasi kerja merupakan Suatu proses atau kekuatan psikologis yang menentukan atau mengarahkan perilaku seseorang di tempat kerja.

\section{METODE}

Penelitian ini menggunakan pendekatan kuantitatif, metode survey dan teknik analisis jalur. Variabel pada analisis jalur terdiri dari variabel eksogen dan variabel endogen. Penelitian ini menggunakan metode field research dengan menggunakan pendekatan analisis jalur, karena metode ini bersifat kuantitatif maka pengolahan data 
menggunakan statistik. Populasi terjangkau penelitian ini adalah guru SMK Negeri di Jakarta Selatan yang berjumlah 278. Dan perhitungan dengan menggunakan slovin, maka di peroleh jumlah sampel sebanyak 164 guru yang dijadikan sampel dalam penelitian ini. Pengumpulan data digunakan untuk penelitian ini adalah statistika deskriptif dan statistika inferensial.

\section{HASIL DAN PEMBAHASAN \\ Pengaruh Kepuasan Kerja terhadap Komitmen Afektif}

Hasil penghitungan koefisien jalur untuk menguji hipotesis diatas disajikan dalam tabel berikut ini:

\section{Tabel 1. Koefisien Jalur Pengaruh} Kepuasan Kerja Terhadap Komitmen

\begin{tabular}{cccccc}
\multicolumn{9}{c}{ Afektif } \\
\hline $\begin{array}{l}\text { Pengaruh } \\
\text { Langsung }\end{array}$ & $\begin{array}{c}\text { Koefisien } \\
\text { Jalur }\end{array}$ & $\mathbf{d k}$ & $\mathbf{t}_{\text {hitung }}$ & $\mathbf{0 . 0 5}$ & $\mathbf{0 . 0 1}$ \\
\hline $\begin{array}{l}\mathrm{X}_{1} \text { terhadap } \\
\mathrm{X}_{3}\end{array}$ & 0.434 & 161 & $6.812^{* *}$ & 1.97 & 2.61 \\
\hline
\end{tabular}

Koefisien jalur sangat signifikan $t_{\text {hitung }}$ $=6,812>\mathrm{t}_{\text {tabel }}=2,61$ pada $\alpha=0,01$. Dari hasil perhitungan analisis jalur, pengaruh langsung Kepuasan Kerja terhadap Komitmen Afektif, nilai koefisien jalur sebesar 0,380 dimana nilai koefisien thitung sebesar 6,812. Nilai Koefisien $\mathrm{t}_{\text {tabel }}$ untuk $\alpha=$ 0,01 sebesar 2,61. Oleh karena nilai koefisien $t_{\text {hitung }}$ lebih besar dari pada nilai $t_{\text {tabel }}$ maka dengan demikian Ho ditolak dan Hi diterima yaitu bahwa Kepuasan Kerja berpengaruh secara langsung terhadap Komitmen Afektif dapat diterima.

Hasil analisis hipotesis pertama memberikan temuan bahwa Kepuasan Kerja berpengaruh secara langsung positif terhadap Komitmen Afektif. Dengan demikian dapat disimpulkan bahwa Komitmen Afektif dipengaruhi secara langsung positif oleh Kepuasan Kerja. Meningkatnya Komitmen Afektif akan mengakibatkan peningkatan Kepuasan Kerja.
Sejalan dengan apa yang dikatakan oleh Menurut Jason A. Colcuitt, Jeffery A. Lepine and Michael J. Wesson: [29] Kepuasan Kerja memiliki pengaruh positif yang kuat terhadap Komitmen Organisasi. Orang yang mengalami tingkat kepuasan kerja yang lebih tinggi cenderung merasakan tingkat Komitmen Afektif yang lebih tinggi.

\section{Pengaruh Motivasi Kerja terhadap Komitmen Afektif}

Hasil penghitungan koefisien jalur untuk menguji hipotesis diatas disajikan dalam tabel berikut ini :

Tabel 2. Koefisien Jalur Pengaruh Motivasi Kerja Terhadap Komitmen Afektif

\begin{tabular}{lccccc}
\hline Pengaruh & Koefisien & dk & $\mathbf{t}_{\text {hitung }}$ & \multicolumn{2}{c}{$\mathbf{t}_{\text {tabel }}$} \\
Langsung & Jalur & $\mathbf{0 . 0 5}$ & $\mathbf{0 . 0 1}$ \\
\hline $\begin{array}{l}\mathrm{X}_{2} \\
\text { terhadap } \\
\mathrm{X}_{3}\end{array}$ & 0.385 & 161 & $6.041^{* *}$ & 1.97 & 2.61 \\
\hline
\end{tabular}

Koefisien jalur sangat signifikan $t_{\text {hitung }}$ $=6,041>t_{\text {tabel }}=2,61$ pada $\alpha=0,01$. Dari hasil perhitungan analisis jalur, pengaruh langsung Motivasi Kerja terhadap Komitmen Afektif, nilai koefisien jalur sebesar 0,320 dan nilai koefisien thitung sebesar 6,041 sedangkan nilai koefisien $t_{\text {tabel }}$ untuk $\alpha=0,01$ sebesar 2,61. Oleh karena nilai koefisien thitung lebih besar dari pada nilai koefisien $t_{\text {tabel }}$ maka Ho ditolak dan Hi diterima, dengan demikian Motivasi Kerja berpengaruh secara langsung terhadp Komitmen Afektif dapat diterima.

Hasil analisis hipotesis kedua menghasilkan temuan bahwa Motivasi Kerja berpengaruh secara langsung positif terhadap Komitmen Afektif. Berdasarkan hasil temuan tersebut dapat disimpulkan bahwa Komitmen Afektif dipengaruhi secara langsung positif oleh Motivasi Kerja. Meningkatnya Motivasi Kerja akan mengakibatkan peningkatan Komitmen Afektif.

McShane dan Von Glinow mengatakan bahwa: [30] Karyawan dengan komitmen afektif yang tinggi juga memiliki motivasi 
kerja dan kewarganegaraan organisasi yang lebih tinggi, serta kinerja pekerjaan yang sedikit lebih tinggi.

\section{Pengaruh Kepuasan Kerja terhadap Motivasi Kerja.}

Hasil penghitungan koefisien jalur untuk menguji hipotesis diatas disajikan dalam tabel berikut ini :

\begin{tabular}{|cccccc} 
Tabel 3. Koefisien Jalur Pengaruh \\
Kepuasan Kerja Terhadap Motivasi \\
Kerja \\
\hline $\begin{array}{c}\text { Pengaruh } \\
\text { Langsung }\end{array}$ & $\begin{array}{c}\text { Koefisien } \\
\text { Jalur }\end{array}$ & $\mathbf{d k}$ & $\mathbf{t}_{\text {thitung }}$ & \multicolumn{1}{c}{$\mathbf{0 . 0 5}_{\text {tabel }}$} & $\mathbf{0 . 0 1}$ \\
\hline $\mathrm{X}_{1}$ terhadap & 0.479 & 161 & $6.751^{* *}$ & 1.97 & 2.61 \\
\hline $\mathrm{X}_{2}$ & & & & & \\
\hline
\end{tabular}

Koefisien jalur sangat signifikan $\mathrm{t}_{\text {hitung }}=$ $6,751>\mathrm{t}_{\text {tabel }}=2,61$ pada $\alpha=0,01$. Dari hasil perhitungan analisis jalur, pengaruh langsung Kepuasan Kerja terhadap Motivasi Kerja, nilai koefisien jalur sebesar 0,649 dimana nilai koefisien $t_{\text {hitung }}$ sebesar 6,751 . Nilai Koefisien $t_{\text {tabel }}$ untuk $\alpha=0,01$ sebesar 2,61 . Oleh karena nilai koefisien $t_{\text {hitung }}$ lebih besar dari pada nilai tabel maka dengan demikian Ho ditolak dan Hi diterima yaitu bahwa Kepuasan Kerja berpengaruh secara langsung terhadap Motivasi Kerja dapat diterima.

Hasil analisis hipotesis ketiga memberikan temuan bahwa Kepuasan Kerja berpengaruh secara langsung positif terhadap Motivasi Kerja. Dengan demikian dapat disimpulkan bahwa Motivasi Kerja dipengaruhi secara langsung positif oleh Kepuasan Kerja. Meningkatnya Kepuasan Kerja akan mengakibatkan peningkatan Motivasi Kerja. Maslow berpendapat bahwa kebutuhan dasar yang paling tidak memuaskan yang menentukan motivasi. Pendapat Maslow ini terindikasi bahwa kepuasan kerja ataupun ketidakpuasan kerja seseorang itu akan menentukan motivasi seseorang.

Herzberg dengan two factor theory mengatakan : [31] Seorang karyawan yang tidak dibayar dengan baik, memiliki keamanan kerja yang sedikit, memiliki hubungan yang buruk dengan rekan kerja dan supervisor (Hygiene factor tidak hadir $=$ ketidakpuasan kerja yang tinggi) dan tidak diberikan tugas yang menantang dan sangat bosan dengan pekerjaannya (motivator tidak ada $=$ kepuasan kerja rendah) tidak akan termotivasi. Teori dua faktor menyiratkan bahwa ketercukupan factor hygiene (faktor kesehatan) dapat menghindari ketidakpuasan, pekerjaan sebgagai perangasang dan bermanfaat sehingga seseorang termotivasi untuk bekerja dan melakukan yang lebih baik.

Hasil penghitungan analisis jalur (path analysis) berdasarkan model empiris penelitian ini ditampilkan dalam diagram pada gambar. 1 .

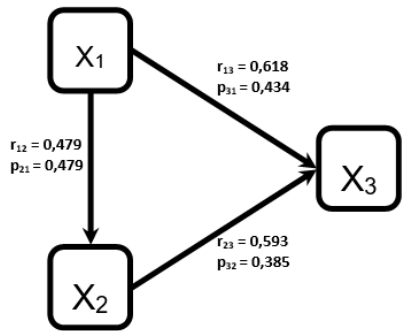

\section{Gambar 1. Model Empiris Antar Variabel}

\section{SIMPULAN}

Berdasarkan hasil dan pembahasan penelitian maka dapat disimpulkan: (1) Kepuasan kerja berpengaruh langsung positif terhadap komitmen afektif, artinya kepuasan kerja guru mengakibatkan peningkatan komitmen afektif guru smk negeri di Jakarta Selatan. (2) Kepuasan kerja berpengaruh langsung positif terhadap komitmen afektif, artinya kepuasan kerja guru mengakibatkan peningkatan komitmen afektif guru smk negeri di Jakarta Selatan. (3) Kepuasan kerja berpengaruh langsung positif terhadap motivasi kerja, artinya kepuasan kerja guru mengakibatkan peningkatan motivasi kerja guru smk negeri di Jakarta Selatan. 


\section{UCAPAN TERIMA KASIH}

Puji syukur kehadirat Allah SWT atas segala Karunia-Nya sehingga artikel ini dapat terselesaikan. Oleh karena itu, penyusun mengucapkan terima kasih yang tulus kepada semua pihak yang telah membantu meyelesaikan artikel ini, khususnya Dosen pembimbing, Kepala Sekolah SMK Negeri di Jakarta Selatan, serta para guru yang telah bersedia menjadi responden penelitian. Semoga Allah SWT membalas dengan pahala yang setimpal. Aamiin.

\section{DAFTAR PUSTAKA}

[1] Engin Karadag, et, al,. A Path Analysis Study of School Culture and Teachers' Organisational Commitment, Policy Future In Education Volume 9 Number 5, 2011, in the Sage Journals, http://journals.sagepub.com (diakses 10 Mei 2018).

[2] Abdeljalil Mohamed Alsiewi and Syed Omar syed Agil, Factors that influence Affective Commitment to teaching in Libya, IOSR Journal of Business and Management Volume 16, 2014, http://iosrjournals.org ( diakses 10 mei 2018).

[3] M. Ivancevich, John., at, al., Organizational Behavior and Management. New York: McGrawHill, 2011.

[4] W. Riffin, Ricky., and Gregory Moorhead, Organizational Behavior: Managing People nad Organizations. USA:South-Western, 2010.

[5] Millward, Lynne., Understanding Occupational and Organizational Psychology. London:SAGE Publications, 2005.

[6] A. Colquitt, Jasson., Jeffery A. LePINE \& Michael J. WESSON, Organization Behavior. Mc Graw Hill, 2015.

[7] L. McShane, Steven., and Mary ann Von Glinow, Organizational Behavior. New York: McGraw-Hill, 2008.
[8] M. George, Jennifer., dan Gareth R. Jones, Organizational Behavior: Understanding and Managing. USA: Prentice Hall, 2012.

[9] Luthans, Fred., Organizational Behavior: An Evidence-Based Approach. New York: McGraw-Hill, 2012.

[10] A. Colquitt, Jasson., Jeffery A. LePINE \& Michael J. WESSON, Organization Behavior. Mc Graw Hill, 2015.

[11] R. Schermerhorn, John., James G. Hunt, Richard N. Osborn, dan Mary Uhl-Blen, Organizational Behavior. USA: John Wiley \& Sons, 2010.

[12] L. McShane, Steven., and Mary ann Von Glinow, Organizational Behavior. New York: McGraw-Hill, 2008.

[13] Kinicki, Angelo., and Robert Kreitner, Organizational Behaviour. New York: McGraw-Hill, 2008.

[14] M. Jex, Steve., Organizational Psychology: A Scientist-Practitioner Approach. New York: John Wiley \& Sons, 2002.

[15] P. Silverthorne, Colin., Organizational Psychology: In Cross-Cultural Perspective. New York: New York University Press, 2005.

[16] P Robbins, Stephen and Timothy A Judge, Organizational Behavior. New Jersey: Perason Prentice Hall, 2007.

[17] Huczynski dan Buchanan, Organizational Behavior. Prentice Hall, 1991.

[18] S.H Hasibuan, Melayu., Manajemen Dasar, Pengertian Masalah. Jakarta: Bina Aksara, 2006.

[19] Syamsudin, Psikologi Kependidikan. Bandung: PT. Remaja Rosdakarya, 2001.

[20] L.Gibson, James., et, al,. Organizations: Behavior, Structure. New York: McGraw-Hill, 2012.

[21] Hellriegel, Don dan John W. Slocum, Organizational Behavior. USA: 
South-Western Cengage Learning, 2011.

[22] Hellriegel, Don dan John W. Slocum, Organizational Behavior. USA: South-Western Cengage Learning, 2011.

[23] Sedarmayanti, Sumberdaya Manusia dan Produktivitas Kerja. Bandung Madar Maju, 2001.

[24] Usman Husaini, Manajemen Teori, Praktik dan Riset Pendidikan. Jakarta: Bumi Aksara, 2006.

[25] M. George, Jennifer., dan Gareth R. Jones, Organizational Behavior: Understanding and Managing. USA: Prentice Hall, 2012.

[26] Kanfer, Ruth., Gilad Chen dan Robert D. Pritchard, Work Motivation:Past, Present, Future. New York: Routledge, 2008.

[27] Jason A. Colcuitt, Jeffery A. Lepine and Michael J. Wesson, Organization Behavior: Improving Performance and Commitment in the Workplace. New York: McGraw-Hill Education, 2015.

[28] Steven L. McShane and Mary Ann Von Glinow, Organizational Behavior. New York: McGraw-Hill, 2008.

[29] James L. Gibson, et, al, Organizations: Behavior, Structure, Processes. New York: McGraw-Hill, 2012. 